\title{
Stretching the Limits? Strengths and Pitfalls of South Atlantic Security Regionalism
}

\section{Pedro Seabra*}

\begin{abstract}
In the broader context of regional studies, the South Atlantic comes across as a singular, yet still understudied case study for the formation, evolution, and regression of security regionalism dynamics. More so when South Atlantic countries have come to engage in increased regionally focused interactions through wider defence co-operation ties. However, they have also steadfastly eschewed any kind of permanent structures and shared sovereignty over sensitive security issues. This article strives to ascertain the limits and prospects of these regional security dynamics in the South Atlantic. With the focal points set on both South American and African shores, I pinpoint key overtures in this area and question their contribution to advancing an overall regionalisation process. Despite shared threat perceptions and an absence of major intra-regional conflicts, I argue that South Atlantic security regionalism lacks a stable and permanent structure inasmuch as it lacks real autonomy from the dictums of external regional powers, thus leaving the transatlantic space still in flux.
\end{abstract}

Keywords: South Atlantic; Brazil; Africa; Security Regionalism; Defence Co-operation.

\section{Introduction}

The notion of structured South Atlantic relations based upon a single collective endeavour or under a common thematic denominator has held a particular appeal over time. During the Cold War, the discursive emphasis on a Soviet build-up in Atlantic waters coupled with the international fallout of the South African Apartheid regime were constantly brought up as reasons to pursue new initiatives in the security domain, albeit with little to no success. But 'despite being pronounced dead on so many occasions, the idea of a South Atlantic pact ... simply refused to die' (Hurrell 1983: 179). In fact, new attempts to readdress the issue and infuse it with new élan have emerged in recent years, while contingent on bursts of leadership by the most preeminent regional actors. Despite steadfastly eschewing any kind of permanent structures or shared sovereignty over sensitive security

\footnotetext{
* GIGA Institute of Latin American Studies, Hamburg, Germany; and University Institute of Lisbon, Lisbon, Portugal; pedronunoseabra@gmail.com.
} 
issues, South Atlantic countries have embarked on increased interactions in the form of transatlantic defence co-operation overtures.

In this context, the South Atlantic comes across as a singular yet still understudied case study for the formation, evolution, and regression of regional dynamics based on security-driven features. Previous contributions have already made significant inroads on the subject, most notably on how Brazil attempts to use its defence co-operation initiatives across the Atlantic in order to instil an emerging regional identity (e.g. Abdenur and Souza Neto 2014). For the purposes of this article, however, I cast a wider and more critical net when regarding this particular area and topic, and seek to both evaluate and ascertain the odds of effective implementation and consolidation of a South Atlantic security regionalism drive. In a rapidly changing landscape that has seen several South American and African juggernauts quickly fall from international and economic grace, the issue incites particular interest over the sustainability of these initiatives and their contextualisation in wider transnational dynamics.

In this kind of analysis, however, multilateral organisations tend to take centre stage, as they are often deemed the main regional engines for the overall provision of security in such spaces (e.g. Tavares 2010; Aris and Wenger 2014). But this choice can also prove problematic, as it leads to an excessive focus on their existence and performance as the sole linchpins of a regionalisation process. More so when considering that the South Atlantic is characterised by the co-existence of different regional bodies and structures, without taking the next step of either additional institutionalisation or shared sovereignty (Abdenur 2014). Hence, and in order to understand the dynamics at play, the focus needs to be turned to summitry mechanisms and exploratory bilateral inroads that might also envision the political construction or, at the very least, the idealisation of a new regionin-the-making through emerging co-operation relations. Concomitantly, this implies subscribing to a more latu sensu definition of security, one in which transatlantic security regionalism can be understood not only as a product of mostly, although not exclusively, military-to-military interactions, but also as a potential conductor for a new regional space precisely structured around such features. It also implies adopting a more analytical approach to the review of these events in order to effectively unpack and expose their different constituting elements.

I begin by exploring the main literature on regionalism in order to demonstrate the limitations inherent in existing frameworks of analysis. This allows me to present a series of benchmarks that escape previous geographic hotspots and can be applicable to the South Atlantic case. I then trace the evolution of defence co-operation overtures throughout the last decade and question their role in either advancing an overall regionalisation process or sustaining a largely hollow regional outcome. With the focal points set on both South American and African shores, I examine existing bilateral ties and ad hoc mechanisms, while also identifying the underlined strengths and pitfalls of the overall discourse behind a new region in the making. The article concludes with some wider implications for further research in this area, as well as with some remarks on a transatlantic scenario still in flux. 


\section{The evolution of security 'regionness'}

The question of what drives regionalism processes and what actually brings countries from one specific region together has remained a central query over the years. The fact that it can be perceived from different perspectives further increases the complexity of the matter. Whether seen from the viewpoint of the actors that drive such efforts, as an incremental process with its own set of variables, or as the outcomes that ultimately emanate from such dynamics, region-building dynamics often prove difficult to grasp in full and even more so when aiming for comparative purposes (Van Langenhove 2012: 18-9). Given this ambivalence, for the purpose of this article, I opt to regard regionalism as 'not only the institutionalisation of trans-border practices but also [as the] reflection of transformations of the regional space' (Riggirozzi and Tussie 2012: 2). This larger canvas allows consideration of varying elements such as shared values, norms, and agendas, as well as the creation and development of new institutional mechanisms.

Further complicating this debate, concepts such as regional integration often intersect with regional co-operation (Börzel 2016: 44). The latter, however, is evidently more loose, flexible and ambivalent than the former and is not necessarily rooted in a permanent institutional structure. It can therefore lead more quickly to sporadic regional efforts focused on specific issues rather than immediately forming an enduring multilateral organisation with wider regional integrative ambitions. But such dynamics remain nonetheless rooted in the active predisposition of key regional paymasters, who are also routinely called upon to assume the role of 'easing distributional tensions and thus smoothing the path of integration' (Mattli 1999: 56). And although 'indicators of "regionness" vary according to the particular problem or question under investigation' (Hurrell 1995: 333-4), the security domain has managed to attract its share of interest over the years.

The first major contribution to the field emerged with Deutsch's study (1957) on security communities. A pluralistic security community was then understood as emerging whenever states became integrated to the point that they achieved a sense of community, which, in turn, created the assurance that they would settle their differences short of war. The topic regained new interest with the constructivist turn in the 1990s, with the most significant contribution originating from Adler and Barnett's proposal (1998) that the evolution of a security community should follow an incremental process. This would allow such projects to be traced from their initial co-ordination stages, where the increase of mutual security and reduction of transaction costs prevails, to a point of increasingly dense networks, institutions, and organisations that reflect tighter co-ordination and cooperation. This also implies sharing common identity traits and, subsequently, the entertainment of dependable expectations of peaceful change.

The extent of this particular framework, however, warranted caution over its widespread application. Hurrell, for instance, pointed out that, only when 'cooperation goes beyond instrumental calculation' and 'the use of force declines' is it possible to consider the validity of the security community concept in its constructivist reinterpretation (1998: 229-30). Moreover, the recurrent requirement of 'a liberal-democratic milieu featuring significant economic interdependence and political pluralism' proved an additional ob- 
stacle (Acharya 1998: 198). Hence, identification of security communities other than the one structured around the North Atlantic remained difficult to achieve. ${ }^{1}$

Seeking to deepen the subject, Buzan and Wæver advanced their own concept of regional security complexes. ${ }^{2}$ Building upon the work carried out under the security community's aegis, regional security complexes thus comprised a 'set of units whose major processes of securitisation, desecuritisation, or both are so interlinked that their security problems cannot reasonably be analysed or resolved apart from one another' (Buzan and Wæver 2003: 44). In other words, such structures were based on dense regions, where security dilemmas can become sharper among proximate actors with shared histories of interaction. Over time, patterns of amity and enmity could arise from these regular transactions, including flows of threats or friendship (Kelly 2007: 206-207).

However, their focus on how geographic density generates interdependence and how security interaction is assumed to be more intense in a locally concentrated area also posed a problem. In other words, it was unclear if participation would be restricted to specific geographical lines or if there were linkages with outside actors. In a revised version of their work, Buzan and Wæver warned against an expanded reach of the concept, given 'that most threats travel more easily over short distances than over long ones' (2003: 11-12). Subsequent adjustments were proposed in which regional security complexes should be understood as a set of states continually affected by one or more security externalities that emanate from a distinct geographic area. This way, limitations over geographic boundaries would be overcome (Morgan 1997: 30). This understanding, however, also warranted criticism for the risk of losing the regional trait per se. Following this rationale to the letter, any great power would be a part of nearly every regional complex in the world, thus transcending the originally intended analysis of sub-systemic dynamics.

A third and more recent attempt to address regional security relations concerns the concept of regional security governance, which views the problematics of international relations as defined by the supply of order and the regulation of conflict without resorting to war (Sperling 2014: 105). Its ultimate purpose is to provide an overarching concept that allows for the dilution of previous frameworks and a more streamlined analysis of regional dynamics. In general terms, the focus is attributed to holistic regional security architectures that foresee formal and informal interactions, via discourse, norms, shared understandings, rules, and practices (Kirchner 2007). Regional security governance is thus brought up whenever possible shared definitions of security issues arise, which can, in turn, be managed and resolved in collaboration beyond the mere national level.

Taken together, these three contributions hold an uncontested centrality amidst attempts to apprehend security-based regional integration dynamics. And even though they do not comprise entirely autonomous theoretical frameworks on their own, they can still assist in informing the analysis of such phenomena while structuring the different embedded features. Given the lack of definitive consensus, one trend in regional security studies seems to reside in combining multiple different concepts, often with mixed results (Serbin and Serbin Pont 2016: 132). Such exercises, however, can prove as frustrating as futile, given that potential comparisons with similar processes in different parts of the world remain invariably lacking. A more analytical approach is therefore required in order to 
ascertain how such dynamics ensue in the present world order. In the upcoming section, I propose taking a step back in this debate and breaking down the components of the process in question.

\section{Unpacking security regionalism}

The South Atlantic consists of a curious case to unpack the elements of an alleged security regionalism drive. Even though countries in this area have often claimed to be working towards bringing the two continental shores together, they nevertheless failed to devise or sustain transoceanic initiatives over time with any meaningful impact. The goal of an exclusive regional security agenda behind the creation of the Zone of Peace and Co-operation in the South Atlantic (ZOPACAS) in 1986 proved short-lived, as the forum faded into institutional hibernation in the following decade. Meanwhile, bilateral security-led co-operative initiatives survived, but remained largely incipient (e.g. Khanyile 2003), that is, until new overtures after the turn of the century began to take place under Brazilian leadership, while infusing them with a new kind of regional discourse (Abdenur and Souza Neto 2014; Duarte 2016). This revamped collective drive became evident as statements by both South African and Brazilian officials exemplify:

We are fortunate to have our brotherly countries from South America, which have co-joined through the waters of the South Atlantic in our quest to seek a better life for all. [...] Our peoples cannot but expect our best efforts in ensuring that this region is free of weapons of mass destruction, narcotics and illegal small arms and weapons (Pahad 2007).

Let us be ambitious. We have our own identity as a region, we are aware of it, and we are proud of it. But that is not enough. It is required that such identity, which is ours, has visibility before the entire world (Patriota 2013, author's translation).

Discourse aside, a series of benchmarks is still required in order to unpack these relations and ascertain their potential towards driving a wider South Atlantic security regionalism process based on key co-operation endeavours. Accordingly, I resort to a framework first proposed by Acharya, who previously deemed military-security co-operation as one of the 'least pronounced and effective aspects of regionalism among Third World countries' (1992: 7). Even though the end of the Cold War spelt out fundamental changes to this rationale, its basic tenets remain valid. Bearing in mind this input, four updated criteria can be presented.

The first concerns the issue of intra-regional conflict. Unless previous or latent conflicts within a selected group of countries are resolved or subsided, it is hard to envision any kind of effective security regionalism thriving under such precarious geopolitical conditions. More so when accounting for how 'regional turmoil' might bring down any hopes of meaningful region formation and instead become a 'pull factor for foreign pow- 
ers' to intervene in the area (Battaglino 2012: 92). Instead of fomenting further intra cooperation, such pending tensions would then in fact work against this. A regional security agenda, loosely conceptualised as it may be, is therefore necessarily contingent on a minimal clean slate within its borders in tandem with a sizeable level of political co-ordination aimed at tackling any unresolved issues that might still linger on.

Secondly, how this co-operation is structured and how it can be successfully operationalised is also key. This can be examined on two distinct sub-levels. The first involves the development and consolidation of formal venues for co-operation that ensures its continuity beyond political-economic cycles. The track record of global South countries in this regard has been noteworthy, with the creation of several overlapping regional security-driven mechanisms over the years (e.g. Weiffen et al. 2013), sometimes even with different overall geographic mandates. But they have also displayed a strong inter-governmental penchant coupled with weak institutional footing, thus warranting legitimate concerns over their operative role on a medium- and long-term basis. A second sub-level concerns how resources, different levels of military capability, and high-politics interests may hamper or foment the formalisation of co-operation relations. Whether or not the content of these dimensions materialises, it can hold back or incite wider regional security ambitions.

Thirdly, it is important to consider the different security agendas that such countries adhere to. The core of any co-operative push needs to address intrastate threats to regional actors inasmuch as external perils. This, in turn, can be based upon multiple threat perceptions as 'anticipations of the future' in terms of the 'expectations aroused in the observer by the perceived infringement' (Cohen 1978: 101). Whether effectively demonstrated or merely hypothetically raised, publically vented appreciations and assumptions of security threats comprise useful indicators of the awareness of regional security problems. Yet, unless shared or given equal priority across time and space, they will invariably fall short of promoting greater collective developments.

And lastly, autonomy, or lack thereof, of this kind of co-operation flows before the surrounding international system also ought to be evaluated. Even though external powers have been generally recognised as important exogenous factors for the development of regionalism (Börzel 2016: 44-5), they can also become possible roadblocks to its implementation. This is particularly so if they serve as alternative security providers that may hold interests of their own in the security and stability of the overall area and thus affect the viability of regionally endogenous solutions. For instance, when analysing the emergence of the South American Defence Council (SADC), Battaglino notes that it was not 'simply the result of US disinterest' in the region but that this new structure also ended up representing a 'reaccommodation of political, economic, military and ideological resources in the management of sovereign decisions in the South' (2012: 98). The reverse situation can be found with regards to Southeast Asia, where the range of regional defence initiatives have been neutralised by the continuing reliance on the security guaranties of external powers (Tan 2012: 240). The full extent of such outer connections should thus be taken into account when ascertaining the emergence of new regional security endeavours. 
Overall, these four criteria - absence of intra-regional conflict, the existence of formal venues and tangible co-operation exchanges, shared security agendas, and autonomy from external powers - can assist in verifying allegations that new regionalisms are presently in the making, while structured around security-driven assumptions.

\section{Testing the limits: South Atlantic security regionalism}

This section breaks down claims of an incremental construction of a South Atlantic regionalism process, while structured on bilateral, multilateral, and transnational co-operation initiatives and on increased exchanges of defence capabilities and know-how across the ocean. Such vectors of engagement towards the South Atlantic have been presented as aiming to instil the notion of a common regional project. Their full content, execution, and overall subscription by the vying partners, however, requires a more fine-tuned analysis while bearing in mind the four criteria previously mentioned. Despite remaining an area still in need of precise delimitation, this exercise attends to the broader geographic limits of the area as the most adequate representation of the dynamics at play.

\section{Intra-regional conflict}

At first glance, the South Atlantic presents itself as an area visibly free of intra-state conflicts in contrast with other regions of the world. Indeed, no particularly major transatlantic conflict or tensions can be found between local state actors. Past regional conflicts, such as Angola's involvement in the DRC, have nearly subsided. And even when the application of international legal mandates proves contentious, issues are often dealt with by the book. The detention of Argentinean frigate Libertad by Ghanaian authorities in 2012, for instance, was ultimately reversed by the International Tribunal for the Law of the Sea (ITLOS) and respected by all parties involved. This helps to fuel a political discourse that South Atlantic countries abide by the 'principles of International Law, including the principles of sovereignty and sovereign equality of states, territorial integrity, settlement of international disputes by peaceful means, and non-intervention in the internal affairs of state' (UNGA 2013).

Such claims find additional corroboration in the declining tokens of armed conflict in the area. That applies more clearly to the South American shores of the Atlantic. ${ }^{3}$ But it also suits the African side, where militarised disputes have strikingly decreased in recent years. ${ }^{4}$ As exhibited in Figure 1, from the total 37 incidents recorded between 1990 and 2010 that involved at least two South Atlantic countries, 25 were initiated during the 1990s. ${ }^{5}$ The later years of the following decade display a visible decrease in registered occurrences. 


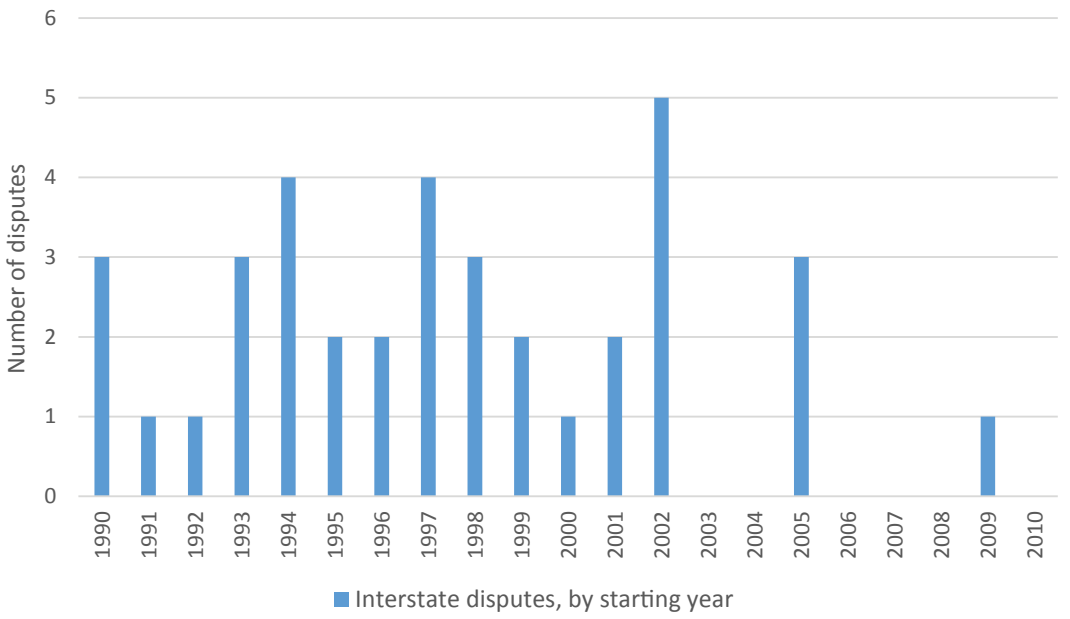

Source: The Correlates of War Project database / compiled by the author

However, despite the validity of such indicators, these results also warrant a measure of caution, as they tend to hide underlined caveats, namely, in the form of unresolved border disputes and tensions that often comprise sources of potential conflict, particularly on African shores. Moreover, areas that lie at the forefront of such disputes also tend to harbour military skirmishes, terrorism, smuggling, ethnic violence, people trafficking, or drug trafficking, thus contributing to overall state and regional instability (Oduntan 2015). Hence, the disruptive potential of these disputes, eventually minimised by the involvement of international legal mechanisms as they may be, cannot be entirely understated and can, in turn, fuel additional regional tensions.

West Africa, in particular, proves a sound example. Recent border disputes have included, for instance, disagreements between Equatorial Guinea and Cameroon over the mouth of the Ntem River, despite a ruling by the International Court of Justice (ICJ) in 2002. The same dispositions apply to the Bakassi peninsula, strategically located in the Gulf of Guinea in between Cameroon and Nigeria. Meanwhile, the dispute over the Gabon-occupied Mbane islands, as well as the maritime boundary of the oil-rich Corisco Bay, continues to pit Equatorial Guinea against Gabon while the settling of a maritime border between Côte d'Ivoire and Ghana awaits a final decision by ITLOS. In Southern Africa, similar contending claims can be found, particularly over river-basin areas. Namibia and South Africa, for example, continue to disagree over their final borders along the Orange River inasmuch as the Congo River presents itself a challenge to establishing a final border delimitation between the Republic of Congo and the DRC.

Widespread findings of large hydrocarbon deposits in the pre-salt layers of both Atlantic margins in the last decade, together with previously existing untapped reserves, have also elevated the risk associated with undefined maritime limits. The DRC, for instance, is involved in a long-standing dispute with Angola over their maritime boundary. In fact, the former's submission in 2013 for the extension of its continental shelf under the 
United Nations Convention on the Law of the Sea (UNCLOS) triggered renewed opposition by the DRC and Gabon, who both argue that it oversteps the area of their own claims. Among several possible headways, legal disputes over the sovereignty of these areas are likely to increase in the coming years, while heralding unpredictable outcomes, and more so given the present South Atlantic context where countries such as Argentina, Brazil, Cape Verde, Gabon, Gambia, Ghana, Guinea, Guinea-Bissau, Namibia, Nigeria, Senegal, Sierra Leone, South Africa, and Uruguay have also already submitted claims in their own right in recent years. ${ }^{6}$ Although not impeditive to any joint co-operative venture ad initio, these formal procedures herald potential diverging views over the control and exploration of similarly coveted areas and can heighten the risk of new disputes.

\section{Structure}

Determining how to effectively structure embryonic co-operation relations is key for their endurance over time. This requirement can be best analysed on two separate but interrelated fronts, namely the current state of formal venues that may underpin such co-operation flows, and the actual content of such relations in terms of meaningful and sustainable inroads that address common South Atlantic security needs.

\section{Venues}

Previous attempts to map the institutional web of potential multilateral security providers in the South Atlantic have confirmed its complex and intertwined nature, often without concrete results to show (Abdenur 2014). That can chiefly be attributed to each organisation's inner workings, whose security dispositions can be either nearly non-existent in terms of the wider maritime domain (e.g. UNASUR) or mostly confined to their own limited shorelines (e.g. ECOWAS, SADC). The most recent attempt to promote tangible intersections only happened upon UN request, when the Economic Community for West African States (ECOWAS), the Economic Community of Central African States (ECCAS), and the Gulf of Guinea Commission (GCC) gathered in Yaoundé, Cameroon, in July 2013 to try to tackle the issue of rising piracy attacks in the Gulf of Guinea. But despite these brewing intra-institutional dialogues, there are still scarce overarching mechanisms with a transatlantic scope that effectively cut across the South Atlantic area and strive to establish regular venues of communications between both margins, much less so in the regional security domain.

An unlikely, if exploratory, case could be made in terms of the wider format of the Africa and South America (ASA) Heads of State and Government summits. Despite a far-ranging agenda focused on multiple sectorial co-operation initiatives, every different meeting (Abuja in 2006, Nueva Esparta in 2009, and Malabo in 2013) has managed to include political-security considerations among the items up for discussion, while emphasising the adoption of 'measures to encourage confidence and co-operation in the fields of defence and security, as the best means to warrant stability, security, democracy, human rights and comprehensive development' (ASA 2009: 19). ${ }^{7}$ Towards that end, the 
implementation plan for 2013-2016 foresaw closer contacts and consultations on security matters of mutual interest, including with third-party institutions such as the African Union Peace and Security Council or the United Nations Peacebuilding Commission, as well as joint initiatives to exchange information and experiences (ASA 2013a). Under the framework of the Peace and Security Working Group, jointly chaired by Argentina and Libya, a workshop over South-South Co-operation on arms control and dual use technologies was even organised in June 2013 in Buenos Aires, which focused on such issues as: small and light weapons; management of security forces arsenals; international transfers of arms; national systems on sensitive exports control; national control mechanisms on chemical substances; nuclear materials security; and schemes of co-operation on training for the detection of illicit traffic (ASA 2013b). Its overall implementation, however, has remained largely incipient and contingent on the fluctuations of national interest in both South America and Africa for the ASA format in itself. Its wide bi-continental focus, on the other hand, also raises legitimate questions over any effective Atlantic-tailored agenda.

The bulk of recent claims over a South Atlantic region in the making have clearly resided in the ongoing attempts to revitalise ZOPACAS. Still, in order to achieve this goal, tokens of proven leadership by a pivot country were invariably required. And much like other integration projects in which it has been involved before, Brazil was faced with a dual expectation and choice of whether or not to assume its condition of regional paymaster. In that sense, after initial exploratory inroads during the Luanda Ministering Meeting of 2007, Brazil began to exhibit a more evident predisposition towards the pickup of ZOPACAS during the subsequent ministerial meeting in Montevideo in 2013, with the aim of adding substance to the transatlantic agenda. That ranged from offers of support over the delimitation of African continental shelves to the exchange of operational experience on peacekeeping and maritime surveillance, and even to the training of specialised human resources. ${ }^{8}$

The common thread to these proposals was straightforward: to increase the consciousness of a common South Atlantic, ideally structured around defence-related initiatives. By attempting to substantiate the revitalisation of ZOPACAS, Brazil sought to tie it to the disbursement of new defence co-operation initiatives that could simultaneously incite greater regional cohesiveness and consolidate its status in the area. Or, to put it differently, ZOPACAS remained a useful venue in the direct proportion of Brazil's willingness and capabilities to both sustain and promote it. Once the country's economic crisis began to take its toll in 2015, however, the willingness and capabilities made available plummeted. The lack of any kind of permanent structure that would allow a more regular workload and ensure a steady flow of interactions further brought such structural dependence into light (Abdenur et al. 2016). The indefinite postponement of the following ministerial meeting scheduled to have taken place in Cape Verde in 2015 further attests to this bleak assessment.

\section{Content}

When taking stock of South Atlantic co-operation in the security and defence domains, two features stand out. On the one hand, the significance of bilateral efforts that, despite 
varying degrees of longevity and success, are often presented as tokens of what could be achieved if a long-term ideal regional scenario is envisioned. On the other hand, the multiplication of international military exercises, which have endured as near-collective endeavours with the purpose of fostering interoperability and common practices between different security sectors on a semi-regular basis.

Bilateral forays have helped to sustain South Atlantic rhetoric over the years. The extensive network of defence attachés established by both Brazil and South Africa, for instance, provided important communication channels for official contacts. ${ }^{9}$ But concrete operational missions are also noteworthy. The Brazilian engagement with Namibia is paradigmatic in that regard. Present on the ground since 1994, the Brazilian Navy took charge of building up its Namibian counterpart through a combination of training opportunities, sale of military hardware, and provision of maritime scientific know-how, while remaining a key partner until today (Seabra 2016). This successful experience then led to recent attempts to replicate the same model in Cape Verde, through the establishment of the Brazilian Naval Mission in August 2013, in charge of assessing local needs. Soon afterwards, the same kind of bilateral engagement was sought out with São Tomé and Principe. Accordingly, in November 2014, the Brazilian Navy Chief of Staff authorised the creation of an embryonic structure on the ground, with the intent of opening a full naval mission in 2015. Meanwhile, the numbers of training slots in Brazilian military institutions for African military personnel visibly increased during the same period (Seabra 2014: 89-91). That same approach has been adopted by such African countries as Nigeria with regard to its own regional neighbours (Ali 2012), as well as by South Africa through the so-called Mission Thebe in the DRC (Vines 2010), in terms of multiple military training opportunities.

Other bilateral initiatives, however, proved less successful. The attempt to install the Missão Brasileira de Cooperação Técnico-Militar (MBCTM - Brazilian Mission for Technical-Military Co-operation) in Guinea-Bissau constituted Brazil's first serious Security Sector Reform (SSR) foray in Africa. However, frequent disruptions of internal order brought this project to a standstill. Likewise, the same could be said of Angola's failed attempt to provide military expertise and capabilities to Guinea-Bissau in 2011. In a rare out-ofarea engagement for a post-civil war nation, the Missão Militar Angolana na Guiné-Bissau (MISSANG - Angolan Military Mission in Guinea-Bissau), composed of over 200 military and policemen, failed to contribute to the resolution of the recurring local politicalmilitary crises.

But despite these efforts towards providing expertise and capabilities beyond each country's sphere of interests, joint military exercises and naval manoeuvres have remained the most constant variable. An enduring example can be found in terms of the ATLASUR naval exercises, which started in 1993 between Argentina and South Africa, with Brazil and Uruguay joining two years later. With ten editions under its belt, it remains the single prevailing token of military-to-military exchanges within the region. In search of new opportunities, in October 2012, a symposium on 'Co-operation between Navies on Security and Situational Awareness in the South Atlantic' was also organised in Rio de Janeiro, with the participation of Angolan, Brazilian, Namibian, and South African officers. The 
intended goals included increased interoperability between the attending navies and the expansion of co-operation in terms of maritime security and naval operations in the South Atlantic.

The most visible outcome of these discussions consisted in triggering preparations for the exercise code-named ATLANTIC TIDINGS. Initially heralded as the exercise which would for the first time bring together the navies of such countries as Angola, Brazil, the DRC, Namibia, and South Africa along the African coastline, it has, however, been mostly characterised by its stillborn nature. Indeed, despite being scheduled for September 2013, it was eventually 'cancelled by the lead nation, Angola, due to capacity challenges' (Department of Defence of South Africa 2014: 80). It has since then been repeatedly postponed, after losing the active participation of the DRC in the meantime.

Two inter-regional endeavours are also worthy of mention due to their evident linkages with the South Atlantic area. On the one hand, the FELINO exercises, organised under the framework of the Comunidade dos Países de Lingua Portuguesa (CPLP - Community of Portuguese Speaking Countries). Since their inception in 2000, seven editions (2002, 2004, 2005, 2006, 2007, 2010, 2013) have taken place on South Atlantic coasts between Angola, Brazil, Cape Verde, and São Tomé and Principe.${ }^{10}$ On the other hand, the IBSAMAR exercise between the navies of Brazil, India, and South Africa has also retained a continuing Atlantic focus. Of the total five editions, the first four (2008, 2010, 2012, 2014) occurred in either Brazilian or South African waters. But despite their inherent contribution to developing regional capabilities and maritime awareness, calls for greater interregional synergies remain doubtful to emerge (Vaz 2015). And much like activities carried out within the ASA framework, these events lack a specific South Atlantic drive, hence contributing to any regionalism drive more by association than by deliberate design.

\section{Agenda}

In order to succeed in its implementation, a regional security agenda needs to be adjusted to the most pressing needs that its constitutive parts face on the ground. Hence, it needs to target both conventional and non-conventional threats that may affect the area in question, while also juggling the main national priorities and calling for the necessary means required for any kind of joint response.

In this context, the bulk of security threats in the South Atlantic have not veered away from what can be found in other international maritime areas, as they assume a clear non-state and non-conventional nature. The issue of piracy, in particular, often associated with other organised criminal activities, began to garner a new focus as it became more violent and organised in the Gulf of Guinea. Countries like Nigeria, Benin, and Togo have comprised the main targets, as pirates take advantage of poor maritime surveillance and still-incipient regional cooperation. ${ }^{11}$ This, in turn, increases the risks over major trade and communications lanes in the area. Transatlantic drug trafficking flows, on the other hand, continue to figure high on the agenda. Due to such local weaknesses as deficient controls at ports and poor inspection equipment, South American drug cartels have targeted Atlantic waters as preferable transit routes for European markets. Invariably, it is 
hard to deny that 'linguistic ties ... play a role in cocaine trafficking from South America to Europe via Brazil, Portugal, and Lusophone countries in Africa' (UNDOC 2013: 43). But while reflecting a growing trend of escalation of the security risks in Atlantic waters and nearby African shores, issues such as piracy or drug trafficking also evidence linkages to structural fragilities present in the security apparatuses of many African countries.

However, despite their visibility and increased magnitude, these threats have come to warrant different degrees of awareness. A sample of four South Atlantic countries, namely Brazil, Cape Verde, South Africa and Uruguay, is taken here as representative of the underlined defence sensibilities and perceptions towards the same overall maritime space, and used as a potential indicator in that regard. ${ }^{12}$ This particular selection provides a balance between regional powers and small states on both shores, with different sets of foreign policy ambitions and material capabilities.

Table 1 - Defence outlooks towards the South Atlantic (Brazil, Cape Verde, South Africa and Uruguay)

\begin{tabular}{|c|c|c|c|c|}
\hline & Brazil & Cape Verde & South Africa & Uruguay \\
\hline Piracy & Unmentioned & $\begin{array}{l}\text { Threat to economic } \\
\text { development }\end{array}$ & $\begin{array}{l}\text { Equalled to trans- } \\
\text {-national and trans- } \\
\text {-oceanic threats }\end{array}$ & Unmentioned \\
\hline $\begin{array}{l}\text { Drug trafficking } \\
\text { and organised } \\
\text { crime }\end{array}$ & Unmentioned & $\begin{array}{l}\text { Equalled to an } \\
\text { external and internal } \\
\text { threat }\end{array}$ & $\begin{array}{l}\text { Possible regional } \\
\text { hub and transit zone } \\
\text { for illicit drugs }\end{array}$ & Unmentioned \\
\hline $\begin{array}{l}\text { Communications } \\
\text { and trade lanes }\end{array}$ & $\begin{array}{l}\text { Obligation to ensure } \\
\text { the security of ma- } \\
\text { ritime communica- } \\
\text { tion and navigation } \\
\text { lanes }\end{array}$ & $\begin{array}{l}\text { Obligation to ensure } \\
\text { the security of navi- } \\
\text { gation routes that go } \\
\text { through the national } \\
\text { maritime space }\end{array}$ & $\begin{array}{l}\text { Obligation to uphold } \\
\text { freedom of seas and } \\
\text { protect the country's } \\
\text { economy }\end{array}$ & $\begin{array}{l}\text { Obligation to } \\
\text { ensure the } \\
\text { surveillance and } \\
\text { control of juris- } \\
\text { dictional waters } \\
\text { and maritime } \\
\text { communication } \\
\text { lanes }\end{array}$ \\
\hline Other threats & $\begin{array}{l}\text { Possibility of } \\
\text { attacks on oil } \\
\text { platforms and naval } \\
\text { installations; war in } \\
\text { the South Atlantic }\end{array}$ & $\begin{array}{l}\text { Non-proliferation; } \\
\text { terrorism; territorial } \\
\text { aggression; natural } \\
\text { disasters }\end{array}$ & $\begin{array}{l}\text { Terrorism; non-pro- } \\
\text { liferation; private } \\
\text { security companies; } \\
\text { natural disasters; } \\
\text { poverty; migra- } \\
\text { tion; food security; } \\
\text { pandemics }\end{array}$ & $\begin{array}{l}\text { Possibility of } \\
\text { extra-regional } \\
\text { conflict in Mal- } \\
\text { vinas }\end{array}$ \\
\hline
\end{tabular}

Source: Systematised by the author

As evidenced in Table 1, some divergence can be found between the national perceptions of the four selected countries when regarding their security and defence priorities towards their maritime domains and, inherently, the overall South Atlantic. In fact, the admission of a possible full-blown war in the area helps to clearly contrast South American and African positions, as the legacy of the Malvinas War is evidently perceived in different measure. Yet despite such individual disparities, a case could still be made that such a comparison is structured on faulty grounds, given that it depends on official orientations that may not sufficiently accompany regional trends or escalating threats. Guinea-Bissau, for instance, comprises a recurrent regional hotspot due to its exposure to drug trafficking routes. And despite lacking formal consecration in Brazilian guidelines, the local context still continues 
to prove worrisome nonetheless, as a former Brazilian Ambassador to Guinea-Bissau made clear during his confirmation hearing:

The thing that is more worrying, not only for the US, who have already stated it, but also for the EU, which in the end is the final consumer, is also the thing that worries Brazil. Why? Of all the drugs that go through the Gulf of Guinea, in the case of Guinea-Bissau, $60 \%$ come from Brazil. Not that they are produced in Brazil, but they circulate through Brazil and from here go there. [...] So, one way or the other, Brazil is involved in this (Federal Senate of Brazil 2007, author's translation).

An alternative source of regional awareness should then be considered. Different multilateral mechanisms in the South Atlantic have come to profess a more cohesive line in terms of the perils that the area faces. The multiple official documents, guidelines, and strategies issued in recent years all point to a similar priority on key security issues. For example, the 2011 SADC Maritime Strategy, the 2013 Gulf Commission Maritime Strategy, the 2013 Code of Conduct for the Gulf of Guinea, and the 2014 ECOWAS Integrated Maritime Strategy - which, together, comprise the canon of African regional orientations towards the Atlantic - subscribe to the same level of priority in dealing with issues of piracy, armed robbery, and illicit maritime activities and have therefore contributed to step up co-ordinated efforts in tackling this kind of threat.

On a more transatlantic note, the final declarations and action plans of both ZOPACAS and ASA Summits also raise the same kind of regional insight that is required in order to incite greater regional responses. Whether stressing 'the need to continue to preserve the South Atlantic region free from the scourge of war, the instability of conflict, drug trafficking, piracy' (UNGA 2013) or reaffirming a 'strong commitment to fight terrorism, piracy, drug trafficking and other forms of organised crimes, including payment of ransom to terrorist groups and international organised crime' (ASA 2013b), it is possible to find increased levels of concertation at a multilateral level. In the case of ZOPACAS, the 2013 meeting even included parallel declarations over the situation in Malvinas, Guinea Bissau, and the DRC as additional tokens of commitment by South Atlantic countries to deal with conflict resolution situations within their own area. Hence, and even though national perceptions might not entirely match, that can be considered as compensated for by an increasing summitry discourse, more flexible and more in tune with current developments, while also more capable of showcasing common regional stances towards security issues in the surrounding maritime area.

\section{Autonomy}

Picturing the South Atlantic without the physical and ideational presence of outside powers is a virtually impossible exercise. The historical track record is rich in developments that have both defined and characterised regional dynamics, including on a security and 
defence level. On that note, the specific legacy of the Malvinas War continues to linger on over the regional agenda, with both the UK and Argentina unable to settle their territorial dispute while often engaging in a routine of public acrimony. New layers of complexity were added after the issue of sovereignty over the surrounding seabed area and associated mineral resources began to take centre stage (Dodds 2016). Moreover, this issue casts a wider spotlight on the remaining overseas maritime territories within South Atlantic limits controlled by outside powers: South Georgia, South Sandwich, Ascension, Saint Helena, and Tristan da Cunha, which can be deemed as geographic roadblocks in the way of wider regional cohesion.

But perceptions of external presence and interference in the South Atlantic are also further heightened when accounting for the military footprint that is found in this area. The use of Ascension's military facilities, together with several unofficial Forward Operations Locations (FOLs) spread throughout the African continent, have proven a recurrent linchpin of the USA's southwards policy. Likewise, French military bases in Côte d'Ivoire, Gabon, and Senegal, as well as the UK-led International Military Advisory and Training Team (IMATT), stationed in Sierra Leone since 2002, continue to house rapid-deployment forces until this day for whenever security hotspots escalate, all the while benefiting from preferential post-colonial security arrangements.

Similar tokens of out-of-area engagement derive from existing military exercises. In fact, the longest standing military exercise in the South Atlantic also comprises the longest serving example of the USA's reach in this area. The United International Anti-Submarine warfare training (UNITAS) started in 1960 with the purpose of providing Argentinean, Brazilian, and Uruguayan navies with opportunities to jointly train with their North American counterpart. Even though it was set up as a complement to the Coordenação Maritima do Atlântico Sul (CAMAS - South Atlantic Maritime Area Command) framework, itself a product of the Inter-American Defence Board (Hurrell 1983: 189), UNITAS survived the changing international context and continues to take place on a regular basis. More recently, news of the reactivation of the US 4th Fleet in 2008 spurred official uproar over the perceived intent to counteract the emergence of new Southern regional powers in their envisioned area of operations. Taken together with the USA's continuing nonratification of UNCLOS, the announcement was used to raise awareness over the need for region-tailored approaches towards maritime areas that did not include outside countries (e.g. Battaglino 2009).

These episodes, however, pale in comparison to developments in the Gulf of Guinea, where external interests and initiatives have multiplied, often in an intertwined fashion. The case of the OBANGAME EXPRESS stands out. Created and led by the US Navy under the African Partnership Station (APS) framework, it has quickly secured the mantle of the single largest multinational exercise in West African waters, with the number of participating nations going from nine in the inaugural 2011 edition to thirty-three in 2016. On the other hand, the Critical Maritime Routes in the Gulf of Guinea (CRIMGO) program, funded and co-ordinated by the European Commission, is presented as a model tool in providing capacity-building expertise to regional countries, through outside support. 
Finally, another clear contrast between regional and outside powers can also be drawn up in terms of the formalisation of co-operation initiatives. South American countries, in particular, proved considerably active in recent years. Between 2003 and 2015, Brazilian authorities pushed for the signing of eight new defence co-operation agreements with African countries in the South Atlantic, in a bid to devise a common framework for their defence co-operation initiatives (Seabra 2014: 87). That included Angola, Guinea-Bissau, Equatorial Guinea, Namibia, Nigeria, São Tomé and Principe, Senegal, and South Africa. On the other hand, Argentina further advanced relations with South Africa through an overall defence co-operation agreement in 2010.

But those efforts have failed to reach the magnitude of the networks previously established, and later reinforced, by external powers. France, for example, currently holds a total of 16 different co-operation agreements in place. Yet, only one country ever succeeded in implementing formal defence relations with every single country in the South Atlantic, namely the USA. Since 1949, a total of 113 formal agreements have been signed with regard to such matters as, for example, the International Military Education and Training Program (IMET) or the Foreign Military Sales Program (FMS)..$^{13}$ At a first glance, it would be easy to attribute such impetus to Cold War predicaments. However, as exhibited in Figure 2, the bulk of these formalities actually originated after the end of the Cold War, thus demonstrating a sustained interest afterwards in security-related developments within this area.

Figure 2 - Defence agreements between the USA and France with South Atlantic countries (1948-2014)

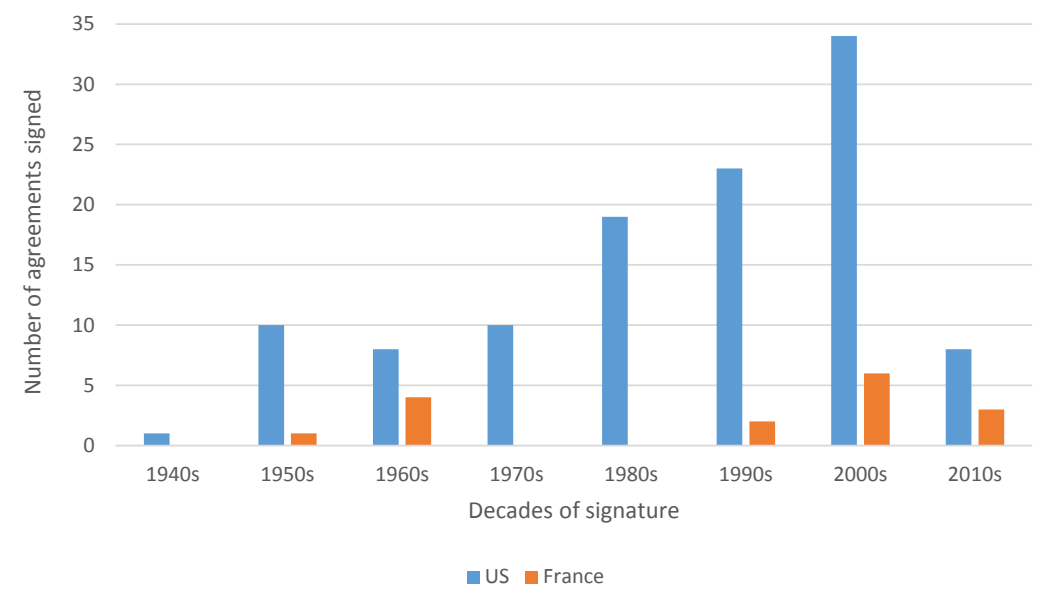

Source: US State Department and French Ministry of Foreign Relations / compiled by the author

Although hardly definitive in itself, this push to formalise security-driven relations with countries in the area may offer tentative grounds to those who attribute a role to the USA as a South Atlantic defence pivot or, at the very least, the more effective one in inciting a common security awareness. Even though autonomy does not equal exclusivity, 
the unparalleled capacities of external powers, coupled with their continuous presence on both Atlantic shores through multiple material means, does highlight a measure of dependence on the security guarantees provide by outer-region actors. It therefore makes it difficult for any security regionalism drive to be implemented and thrive on its own.

\section{Conclusion}

The significance of regions in the international system has proved a contentious issue in light of the push of globalisation. But the claim that 'globalization is encouraging a regional pushback' has also proved appealing in recent decades, with interest in new regionalist takes spiking in equal measure (Kelly 2007: 197; e.g. Mattheis 2014). In this context, security regionalism has not remained immutable. Still, and despite different contributions over the years, no existing proposal has yet been able to fully grasp evolving dynamics that aspire to form a new regionalism process structured around security-driven issues. Recent literature trends appear to favour a regional governance conceptualisation over previous one-size-fits-all solutions like the security communities' framework or overly flexible models like regional security complexes (Kacowicz and Press-Barnathan 2016). But, as this article demonstrates, a focus on specific modalities of regional co-operation that may incite and drive a wider regionalisation process might just herald equally satisfactory results in unpacking potential regions in the making. This does not mean that the criteria adopted can fit or encapsulate every series of similar dynamics in the world at large. The issue of how to apprehend the role of external powers in either inciting or blocking this kind of development in the security domain, for instance, will always vary from case to case, depending on the historical track record and previously existing engagements. But the criteria's general utility remains in terms of uncovering the strengths and pitfalls of any official discourse that attempts to construct a regional project based on a top-down approach.

However, this also raises a second batch of problems by highlighting the inherent limits of any overtly regional initiative nowadays. Latin American regionalism, for example, is considered to have 'reached a peak beyond which it will be unable to progress. Yet, the exhaustion of comprehensive integration projects does not mean that regional cooperation will not take place, but rather that the 'pooling or delegation of sovereignty will no longer be an option' (Malamud and Gardini 2012: 125). These same conclusions could be transplanted to the South Atlantic case, where regional co-operation is likely to continue in some measure but unlikely to evolve into any kind of more meaningful regional integration.

This downsizing of expectations over the build-up of a new regional drive in the South Atlantic can be inferred from the analysis of the ongoing endeavours targeted by this article, following the proposed criteria. To be sure, significant ties in the security and defence domain have indeed emerged over the years between both shores at the same time as intra-state conflict have markedly declined within the area. Even though this peaceful evolution may abide more with a wider global trend rather than a strictly regional one, it 
has positively influenced regional developments nonetheless. Moreover, previous existing defence co-operation initiatives have been used as springboards for greater interactions while military exercises have multiplied in number and substance. These factors alone are significant enough to increase the odds of effectiveness behind a new regional discourse, in stark contrast to previous attempts made during the Cold War.

Yet, wider regional achievements have also been chronically dampened by a pattern of irregularity in the workload of multilateral gatherings and a clear preference for declaratory commitments instead of formal obligations. That invariably makes claims of a South Atlantic security regionalism stand out as extremely diffuse in its goals and occasionally hollow in its accomplishments. Simultaneously, this has led to far more concrete developments on the African side of the South Atlantic, exclusively focused on pressing African issues rather than on transatlantic opportunities per se. This 'tyranny of geography' inherent to the vastness of the oceanic space in between also contributes to the maintenance and expansion of security ties with outer-region actors. With no evident regional paymaster or pivot leader in sight and with Brazil on a reverse course from the previously exhibited South Atlantic impetus between 2003 and 2014, outside competition and alternatives to strictly regional endeavours are bound to remain valid options and undercut the purpose of more autonomous solutions.

Hence, and much like what can be observed with other similar case studies in Southeast Asia, it is possible to argue that the South Atlantic still 'lacks the strategic imperative and institutional coherence befitting a model of regionalism' (Tan 2012: 231). In other words, South Atlantic security regionalism lacks a stable and permanent structure inasmuch as it lacks real autonomy from the dictums of external powers to the area. Shared threat perceptions can only do so much as aggregating regional leitmotivs, and the current absence of major intra-regional conflicts does not necessarily imply this option has been wholly discarded.

While not definitive, this analysis has highlighted dynamics that clearly warrant further observation. Specifically, more focus needs to be given to African perceptions of Atlantic security issues, given that public debate on the topic has come to overwhelmingly adhere to Brazil's lead in recent years. Likewise, the growing interest in South Atlantic security issues by extra-regional players such as China or the linkages between security endeavours and more ambivalent activities, like the provision of technical-scientific cooperation, have also yet to be sufficiently explored and intersected. The same applies to how the private sector and, more particularly, national defence industry conglomerates in both margins have contributed to stoking official interest in these developments. However, a key question still remains: Can security and defence overtures ever instil a sustainable regionalisation process in the South Atlantic? The consequences of this state of affairs do not curtail any other leitmotivs (e.g. trade; energy) from bringing countries in this area together, inasmuch as it happened in other parts of the world. But it does signal that the limits of the South Atlantic will remain invariably stretched if they are to be based on security tenets alone, while seeking to promote a region of its own. 


\section{Notes}

1 The shortcomings of their framework were admitted by Adler and Barnett themselves when in their edited volume, 'nearly all the contributors found that their case deviated in significant ways from the model.' This led them to conclude that 'the insufficiency of the [proposed] indicators does not jettison their utility per se but rather questions their validity' (1998: 431, 434).

2 Also worthy of mention is the research carried over the issue of zones of peace and its ties to the necessity (or lack thereof) of a democratic regime to the ultimate development of a pluralistic security community (Kacowicz 1995).

3 That assessment changes, however, if we choose to adopt a wider Latin American perspective (Mares 2012).

4 Militarised interstate disputes are here defined as 'united historical cases of conflict in which the threat, display or use of military force short of war by one member-state is explicitly directed towards the government, official representatives, official forces, property, or territory of another state. Disputes are composed of incidents that range in intensity from threats to use force to actual combat short of war' (Jones et al. 1996: 168).

5 Disputes involving external powers with territories in the South Atlantic are addressed in the Autonomy section.

6 Unlike the other countries, which have pursued individual claims, Cape Verde, Gambia, Guinea, GuineaBissau, Senegal, and Sierra Leone - together with Mauritania - submitted a joint submission in 2014 with regard to adjacent areas on their West African coasts.

7 The fourth summit was expected to have taken place in May 2016 in Ecuador but has since been postponed.

8 In November 2013, Brazil organised a training workshop on maritime search and rescue in Salvador. A second joint seminar on the planning, management, and execution of peacekeeping operations, also to be organised by Brazil, was expected to take place in 2014 but was subsequently postponed indefinitely.

9 By 2013, Brazil had defence attachés in Angola (with accreditation in São Tomé and Principe), Argentina, Cape Verde, Namibia, Nigeria (with accreditation in Ghana), Senegal (with accreditation in Benin and Togo), South Africa, and Uruguay. Likewise, negotiations began to include the DRC in this network. In return, Angola, Argentina, Namibia, Nigeria, Senegal, South Africa, and Uruguay maintain defence attachés stationed in Brasilia. On the other hand, by 2015 South Africa had resident defence attachés in Angola, Argentina, Brazil, Côte d'Ivoire, the DRC, Namibia, and Nigeria, as well as non-resident representation in Congo-Brazzaville, Ghana, and Uruguay. In return, Angola, Argentina, Brazil, Cameroon, Côte d'Ivoire, the DRC, Congo-Brazzaville, Equatorial Guinea, Gabon, Namibia, Nigeria, and Senegal maintain defence attachés stationed in Pretoria.

10 Within this institutional format, the second and third Symposiums of CPLP Navies also took place in Angola and Brazil in 2010 and 2012, respectively.

11 Records of both committed and attempted acts of piracy and armed robbery have stabilised in recent years: 61 in 2011; 64 in 2012; 54 in 2013; and 41 in both 2014 and 2015. These attacks occurred in an area that included such countries as Angola, Benin, Cameroon, Cape Verde, Congo, Côte d'Ivoire, the DRC, Equatorial Guinea, Gabon, Gambia, Ghana, Guinea-Bissau, Guinea-Conakry, Liberia, Nigeria, Senegal, Sierra Leone, Sao Tome and Principe, and Togo (ICC International Maritime Bureau 2016: 5).

12 The comparison in Table 1 is based upon five key documents from the selected sample of South Atlantic countries: the 2012 updated versions of the Brazilian National Defence Strategy and the National Defence Policy; the 2011 Cape Verdean Strategic Concept for Defence and National Security; the 2014 South African Defence Strategic Review; and the 2014 Uruguayan National Defence Policy. Threat perceptions and priorities were extracted whenever explicitly tied to each country's maritime interests.

13 The graphic depiction in Figure 2 includes every formal agreement labelled by the US State Department and the French Ministry of Foreign Relations as falling under the defence-military domain and currently still in force with countries from both sides of the South Atlantic. Despite not yet being mentioned in the US State Department's official tally, the new agreement signed with Senegal in May 2016 was also accounted for. 


\section{References}

Abdenur, Adriana Erthal. 2014. 'Security and Cooperation in the South Atlantic: The Role of Regional Organizations'. In Atlantic Currents: An Annual Report of Wider Atlantic Perspectives and Patterns. Washington DC and Rabat: German Marshall Fund of the US and OCP Policy Center, pp. 98-112.

Abdenur, Adriana Erthal and Danilo Marcondes Souza Neto. 2014. 'O Brasil e a cooperação em defesa: a construção de uma identidade regional no Atlântico Sul'. Revista Brasileira de Política Internacional, 57 (1): 5-21.

Abdenur, Adriana Erthal, Frank Mattheis and Pedro Seabra. 2016. 'An ocean for the Global South: Brazil and the zone of peace and cooperation in the South Atlantic'. Cambridge Review of International Affairs, vol. 29 (3): 1112-31.

Acharya, Amitav. 1992. 'Regional Military-Security Cooperation in the Third World: A Conceptual Analysis of the Relevance and Limitations of ASEAN (Association of Southeast Asian Nations)'. Journal of Peace Research, 29 (1): 7-21.

1998. 'Collective identity and conflict management in Southeast Asia'. In Emanuel Adler and Michael Barnett (eds), Security Communities. Cambridge: Cambridge University Press, pp. 198-227.

Adler, Emanuel and Michael Barnett. 1998. 'Studying security communities in theory, comparison, and history'. In Emanuel Adler and Michael Barnett (eds), Security Communities. Cambridge: Cambridge University Press, pp. 413-41.

Africa-South America Heads of State and Government Summit. 2009. Declaration of the Second Africa-South America Summit - Isla Margarita, September 27, 2009.

2013. Inputs of Working Groups - Africa-South America Implementation Plan 2013-2016.

2013. Report of Workshop on South-South Cooperation on Arms Control and Dual Use Technologies - Buenos Aires, June 3-4, 2013.

Ali, W.O. 2012. The Role of Nigeria in Regional Security Policy. Abuja: Friedrich-Ebert-Stiftung.

Aris, Stephen and Andreas Wenger (eds). 2014. Regional Organizations and Security: Conceptions and practices. London: Routledge.

Battaglino, Jorge. 2009. 'A reativação da IV Frota e o novo paradigma de controle global dos Estados Unidos'. Política Externa, 17 (4): 31-47.

2012. 'Defence in a Post-Hegemonic Regional Agenda: The Case of the South American

Defence Council'. In Pia Riggirozzi and Diana Tussie (eds), The Rise of Post-Hegemonic Regionalism: The Case of Latin America. Heidelberg: Springer, pp. 81-100.

Börzel, Tanja A. 2016. 'Theorizing Regionalism: Cooperation, Integration, and Governance'. In Tanja A. Börzel and Thomas Risse (eds), The Oxford Handbook of Comparative Regionalism. Oxford: Oxford University Press, pp. 41-63.

Buzan, Barry and Ole Wæver. 2003. Regions and Powers: The Structure of International Security. Cambridge: Cambridge University Press.

Cohen, Raymond. 1978. 'Threat Perception in International Crisis'. Political Science Quarterly, 93 (1): 93-107. 
Department of Defence of South Africa. 2014. Annual Report FY 2013/2014. Cape Town: Department of Defence.

Deutsch, Karl W, Sidney A Burrell, Robert A Kann, Maurice Lee Jr, Martin Lichterman, Raymond E. Lindgren, Francis L. Loewenheim, and Richard W. Van Wagenen. 1957. Political Community and the North Atlantic Area: International Organization in the Light of Historical Experience. Princeton: Princeton University Press.

Dodds, Klaus. 2016. 'Our seabed? Argentina, the Falklands and the wider South Atlantic'. Polar Record, 52 (5): 535-540.

Duarte, Érico. 2016. 'Brazil, the Blue Economy and the maritime security of the South Atlantic'. Journal of the Indian Ocean Region, 12 (1): 97-111.

Federal Senate of Brazil. 2007. 'Ata da Comissão Permanente do Senado Federal, referente a 45a Reunião Ordinária de 13/12/2007 da Comissão: CRE - Comissão de Rel. Exteriores e Def. Nacional'. At https://legis.senado.leg.br/comissoes/comissao?8\&codcol=54 [Accessed on 15 June 2016].

Hurrell, Andrew. 1983. 'The politics of South Atlantic security: a survey of proposals for a South Atlantic Treaty Organization'. International Affairs, 59 (2): 179-93.

1995. 'Explaining the Resurgence of Regionalism in World Politics'. Review of International Studies, 21 (4): 331-58.

1998. 'An emerging security community in South America?'. In Emanuel Adler and Michael Barnett (eds), Security Communities. Cambridge: Cambridge University Press, pp. 228-64.

ICC International Maritime Bureau. 2016. Piracy and Armed Robbery Against Ships. Report for the period 1 January-31 December 2015. London: ICC-IMB.

Jones, Daniel M, Stuart A Bremer and J David Singer. 1996. 'Militarized Interstate Disputes, 18161992: Rationale, Coding Rules, and Empirical Patterns'. Conflict Management and Peace Science, 15 (2): 163-213.

Kacowicz, Arie M. 1995. 'Explaining Zones of Peace: Satisfied Democracies?' Journal of Peace Research, 32 (3): 265-76.

Kacowicz, Arie M and Galia Press-Barnathan. 2016. 'Regional Security Governance'. In Tanja A. Börzel and Thomas Risse (eds), The Oxford Handbook of Comparative Regionalism. Oxford: Oxford University Press, pp. 297-321.

Kelly, Robert E. 2007. 'Security Theory in the "New Regionalism”'. International Studies Review, 9 (2): 197-229.

Khanyile, Moses Bongani. 2003. South Africa's Security Relations with the MERCOSUR Countries. $\mathrm{PhD}$ Thesis, University of Pretoria, South Africa.

Kirchner, Emil. 2007. 'European Union: The European Union Security Strategy Versus National Preferences'. In Emil Kirchner and James Sperling (eds), Global Security Governance: Competing Perceptions of Security in the 21 $1^{\text {st }}$ Century. London and New York: Routledge, pp. 113-33.

Malamud, Andrés and Gian Luca Gardini. 2012. 'Has Regionalism Peaked? The Latin American Quagmire and its Lessons'. The International Spectator: Italian Journal of International Affairs, 47 (1): 116-33.

Mares, David. 2012. Latin America and the Illusion of Peace. London: Routledge.

Mattheis, Frank. 2014. New regionalism in the South - Mercosur and SADC in a comparative and interregional perspective. Leipzig: University of Leipzig. 
Mattli, Walter. 1999. The Logic of Regional Integration: Europe and Beyond. Cambridge: Cambridge University Press.

Morgan, Patrick. 1997. 'Regional Security Complexes and Regional Orders'. In David Lake and Patrick Morgan (eds), Regional Orders: Building Security in a New World. University Park: Pennsylvania State University, pp. 20-42.

Oduntan, Gbenga. 2015. International Law and Boundary Disputes in Africa. London: Routledge.

Pahad, Aziz. 2007. 'Address to the 6th Ministerial Meeting of the Zone for Peace and Cooperation in the South Atlantic, Deputy Minister Aziz Pahad - Republic of South Africa, 18 June 2007, Luanda, Angola. At http://www.dirco.gov.za/docs/speeches/2007/paha0620.htm [Accessed on 15 June 2016].

Patriota, Antonio. 2013. 'VII Reunião Ministerial da Zona de Paz e Cooperação do Atlântico Sul (ZOPACAS) - Texto-base do discurso do Ministro Antonio de Aguiar Patriota - Montevidéu, 15 de Janeiro de 2013'. At http://www.itamaraty.gov.br/pt-BR/discursos-artigos-e-entrevistas/ministrodas-relacoes-exteriores-discursos/4547-vii-reuniao-ministerial-da-zona-de-paz-e-cooperacao-doatlantico-sul-zopacas-texto-base-do-discurso-do-ministro-antonio-de-aguiar-patriota-montevideu-15-de-janeiro-de-2013 [Accessed on 15 June 2016].

Riggirozzi, Pia and Diana Tussie. 2012. 'The Rise of Post-Hegemonic Regionalism in Latin America'. In Pia Riggirozzi and Diana Tussie (eds), The Rise of Post-Hegemonic Regionalism: The Case of Latin America. Heidelberg: Springer, pp. 1-17.

Seabra, Pedro. 2014. 'A harder hedge: reframing Brazil's power relations with Africa'. Revista Brasileira de Política Internacional, 57 (1): 77-97.

2016. 'Defence cooperation between Brazil and Namibia: Enduring ties across the South Atlantic'. South African Journal of International Affairs, 23 (1): 89-106.

Serbin, Andrés and Andrei Serbin Pont. 2016. 'Cooperative security and regional governance'. In David R. Mares and Arie M. Kacowicz (eds), Routledge Handbook of Latin American Security. London and New York: Routledge, pp. 127-37.

Sperling, James (ed.). 2014. Handbook of Governance and Security. Cheltenham, Glos., UK: Edward Elgar Publishing.

Tan, See Seng. 2012. “Talking Their Walk”? The Evolution of Defense Regionalism in Southeast Asia. Asian Security, 8 (3): 232-50.

Tavares, Rodrigo. 2009. Regional Security: The Capacity of International Organizations. London and New York: Routledge.

United Nations General Assembly (UNGA). 2013. 'Annex I and II - Seventh Ministerial Meeting of the Zone of Peace and Cooperation of the South Atlantic, Montevideo Declaration and Action Plan - A/67/746. At http://www.un.org/en/documents/ods/ [Accessed on 15 June 2016].

United Nations Office on Drugs and Crime (UNDOC). 2013. World Drug Report 2013. Vienna: UNDOC.

Van Langenhove, Luk. 2012. 'Why We Need to 'Unpack' Regions to Compare Them More Effectively'. The International Spectator: Italian Journal of International Affairs, 47 (1): 16-29.

Vaz, Alcides Costa. 2015. 'Brazilian approaches to maritime security cooperation in IBSA and the prospects for an Atlantic-Indian maritime security governance'. Journal of the Indian Ocean Region, $11(2): 170-183$. 
Vines, Alex. 2010. 'South Africa's politics of peace and security in Africa'. South African Journal of International Affairs, 17 (1): 53-63.

Weiffen, Brigitte, Leslie Wehner and Detlef Nolte. 2013. 'Overlapping regional security institutions in South America: The case of OAS and UNASUR'. International Area Studies Review, 16 (4): 370389.

\section{Acknowledgements}

The author wishes to thank Andrés Malamud, Débora Terra and two anonymous reviewers for valuable comments on earlier drafts of this article. Full responsibility for the final content, however, remains with the author alone.

\section{About the author}

Pedro Seabra is a Leibniz-DAAD Research Fellow at the German Institute of Global and Area Studies, Hamburg, Germany (GIGA), and a Researcher at the Center for International Studies, University Institute of Lisbon, Portugal (CEI-IUL). He holds a PhD in Political Science from the Institute of Social Sciences, University of Lisbon (ICS-ULisboa). He has been a Visiting Researcher at the Institute of International Relations-University of Brasília, Brazil (IREL-UnB), at the Centre for the Study of Governance Innovation, University of Pretoria, South Africa (GovInn-UP) and at the ICS-ULisboa. His main research interests focus on international relations, South Atlantic geopolitics, and security capacity-building in Africa. His recent publications include book chapters, articles, and reports on such topics.

Received on 23 June 2016 and approved for publication on 11 January 2017.

\section{(cc) BY-NC} https://creativecommons.org/licenses/by-nc/4.0/ 